HORTSCIENCE 26(3):271-273. 1991.

\title{
Movement of Boron Out of Tree Fruit Leaves
}

\author{
Eric J. Hanson \\ Department of Horticulture, Michigan State University, East Lansing, \\ MI 48824-1325 \\ Additional index words. phloem, mobility, stable isotopes, Malus domestics, Pyrus \\ communis, Prunus domestics, Prunus cerasus
}

\begin{abstract}
Foliar B sprays (500 mg.liter $\left.{ }^{-1}\right)$ had increased the B content of apple (Malus domestics Borkh), pear (Pyrus communis L.), plum (Prunus domestics L.), and cherry (Prunus cerasus L.) leaves $90 \%$ ) to $185 \% 3$ days after treatment. Boron levels in treated apple, pear, and plum leaves decreased to levels similar to nontreated leaves by 9 days after application, whereas cherry leaves required 33 days to approach levels in nontreated leaves. Movement of applied $B$ was also studied by treating cherry leaves with $B$ solutions enriched in the stable isotope, ${ }^{10} B$. Isotope analysis indicated that applied $B$ moved out of leaves and into subtending tissues. The highest concentrations of applied $B$ were found in buds, followed by bark and wood.
\end{abstract}

Symptoms of boron (B) deficiency nearly always occur first in actively growing tissues (Eaton, 1944). This pattern indicates that B does not move readily from mature plant parts to growing tissues and implies that $\mathrm{B}$ is not highly mobile within the phloem relative to many nutrient elements (Mengel and Kirkby, 1987). Epstein (1973) suggested that the exclusion of $\mathrm{B}$ from the phloem maintains phloem function, because $\mathrm{B}$ injections into petioles caused heavy plugs of callose to form in sieve tubes (Eschrich et al., 1965). Oertli and Richardson (1970) proposed a theory that explained the limited movement of B out of leaves based on the loss of B from phloem to xylem.

Although the phloem mobility of B is generally limited, transport may occur under some conditions. Boron concentrations in mature leaves of broccoli, grapes, cotton, and turnip

Received for publication 18 May 1990. I acknowledge the Michigan Agricultural Experiment Station for support of this research. The cost of publishing this paper was defrayed in part by the payment of page charges. Under postal regulations, this paper therefore must be hereby marked advertisement solely to indicate this fact. plants declined when $\mathrm{B}$ was witheld from the root environment (Benson et al., 1961; McIlrath, 1965; Scott and Schrader, 1947), suggesting remobilization of B from leaves. Similarly, B concentrations in plum leaves decreased soon after B was applied to leaves in the fall (Hanson et al., 1985).

Although the lack of a convenient radioisotope of B has hampered mobility studies, two stable isotopes $\left({ }^{10} \mathrm{~B},{ }^{11} \mathrm{~B}\right)$ have become useful. Martini and Thellier (1975) traced the movement of ${ }^{10} \mathrm{~B}$-enriched $\mathrm{B}$ from clover leaves, using a nuclear reaction to distinguish between B isotopes. Spark-source mass spectrometry has also been useful in studying the movement of $\mathrm{B}$ isotopes in plants (Charnel and Andreani, 1985; Charnel et al., 1981). Inductively coupled plasma-mass spectrometry (ICP-MS) was a sensitive technique for determining ${ }^{10} \mathrm{~B}:{ }^{11} \mathrm{~B}$ ratios in geological materials (Gregoire, 1987) and has recently been used to study the transport of Bin peach seedlings (Zen-Hong et al., 1989).

Greater knowledge of B transport in plants may help avoid some deficiency disorders and increase the effectiveness of foliar applications. Cork spot in apple fruit (Wightman et al., 1970), surface spotting of pear 


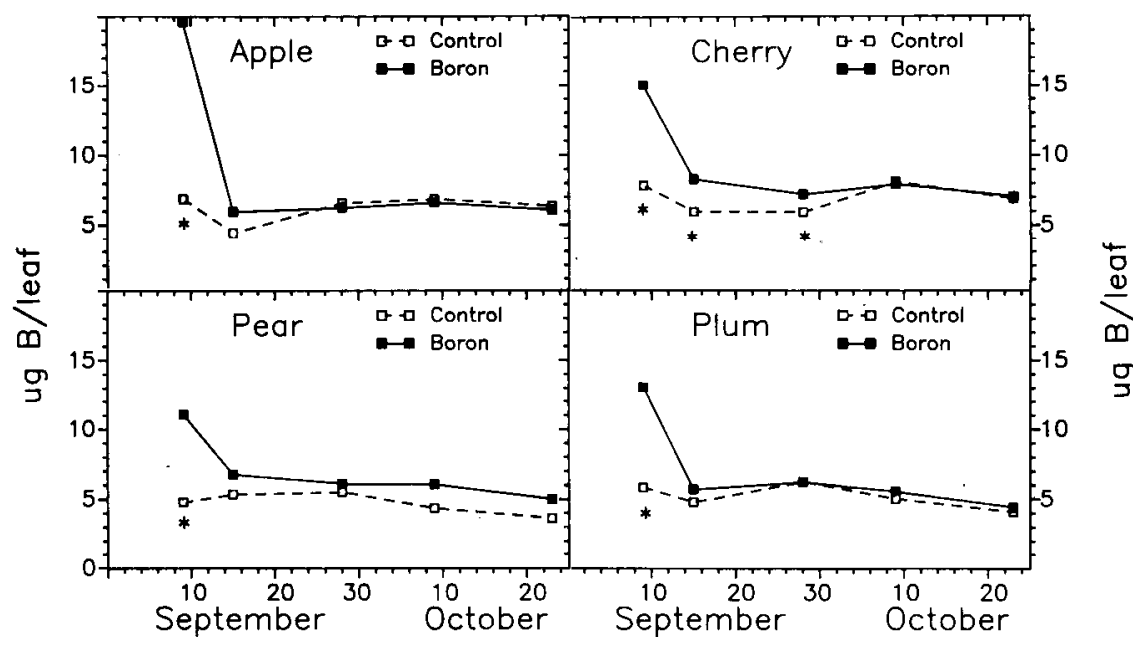

Fig. 1. Change in B content of leaves treated with sprays of $500 \mathrm{mg} \cdot$ liter $^{-1}$ on 6 Sept. 1988 compared to controls. Significant $(*)$ difference between treatments, $P=0.05, F$ test.

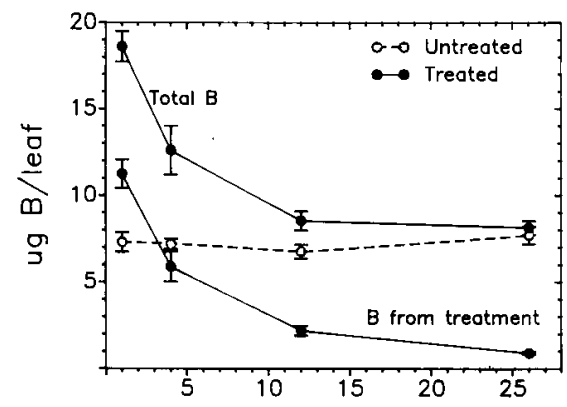

Days After Treatment

Fig. 2. Effect of ${ }^{10} \mathrm{~B}$-enriched $\mathrm{B}$ solutions $(500$ $\left.\mathrm{mg} \cdot \mathrm{liter}^{-1}\right)$, applied to 'Montmorency' sour cherry leaves on 16 Sept. 1989, on total B content and $B$ derived from applied solutions. Points represent the means of six observations $\pm S E$.

fruit (Kienholz, 1942), and brown-heart of rutabaga roots (Gupta and Munro, 1969) are localized disorders associated with low B levels in specific organs and that may result, in part, from the limited mobility of $B$ in plants. The degree to which foliar-applied B is remobilized from leaves likely influences how effective sprays are in correcting deficiencies. This work was conducted to determine how much $B$ is remobilized from leaves following foliar applications and whether the mobility of B differs in several tree fruit species.

Potential species differences were studied by applying B sprays to 'Bartlett' pears (5year-old trees), 'Starking Delicious' apple (30 years old), 'Montmorency' sour cherry ( 7 years old), and 'Stanley' plum (10 years old) in East Lansing, Mich. Experimental units consisted of two trees that were replicated five times for each species. Two 50- to 100$\mathrm{cm}$-long branches per tree (four/plot) containing an estimated 100 to 300 spur leaves each were sprayed to the point of drip with Solubor (U.S. Borax and Chemical Corp., Los Angeles) on 6 Sept. 1988. The solution contained $500 \mathrm{mg}$ B/liter. The same number of nonsprayed branches served as controls. Exposed branches were selected around the perimeter of trees to maximize the distance between branches on the same tree. Fruit load on the apple and pear trees was light, and test branches without fruit were used. Plum trees were fruiting, and all test branches carried fruit at the time of application. Cherry trees were also fruiting, and most test branches carried fruit earlier in the season.

Ten spur leaves were collected from each plot (two to three per branch) 3, 9, 22, 33, and 47 days after treatment. Leaves were washed for $1 \mathrm{~min}$ in distilled water and dried at $65 \mathrm{C}$ for 4 days. Leaf dry weight was recorded and tissue was ground in a Wiley mill to pass a 40-mesh screen. Samples were ashed in a muffle furnace at $500 \mathrm{C}$ for $6 \mathrm{~h}$. Ash was (as a matrix modifier) and analyzed for total $B$ with a direct-current plasma emission spectrophotometer (Beckman Instruments, Fullerton, Calif.)

A second trial traced the movement of $\mathrm{B}$ in sour cherry using stable isotopes. A solution of $500 \mathrm{mg} \mathrm{B} /$ liter was prepared using 96.75 atom \% ${ }^{10} \mathrm{~B}$-enriched boric acid (Eagle-Picher Industries, Quapaw, Okla.). The apical $20-\mathrm{cm}$ portion of six branches was marked on each of five 25-year-old 'Montmorency' sour cherry trees, Six additional branches on the same trees served as controls. Individual leaves on each branch were immersed briefly in the B solution on 16 Sept. 1989. Leaves were gently shaken to remove excess solution and to prevent dripping onto nonleaf tissues. Twelve leaves (two from each branch) were collected from treated and control branches an each tree 1, 4, 12, and 26 days after treatments. Treated and control branches were removed on 2 Nov., after nearly all leaves had abscised naturally. Additional 20-cm-long basal sections of branch were removed adjacent to each treated length. Representative samples of dormant buds, bark, and wood were collected.

Leaf, bud, bark, and wood tissues were prepared and analyzed for total $\mathrm{B}$ as described above. Isotopic ${ }^{10} \mathrm{~B}:{ }^{11} \mathrm{~B}$ ratios were determined on the same sample solutions using a ELAN 500 ICP-MS (Perkin Elmer Corp., Norwalk, Corm.), National Bureau of Standards isotopic standard SRM 951 (Boric acid, dissolved in $3 \mathrm{~N} \mathrm{HNO}_{3}$ with $1000 \mathrm{mg} \mathrm{Li} /$ liter
${ }^{10} \mathrm{~B}:{ }^{11} \mathrm{~B}=0.2473$ ) was used as preference.

The contribution of applied B to total tissue $B$ was calculated using equations for ${ }^{\text {l }} \mathrm{N}$ enrichment studies (Rennie and Rennie, 1983): Atom $\%{ }^{10} \mathrm{~B}$ excess $=$ atom $\%{ }^{10} \mathrm{~B}$ (measured in sample) - atom $\%{ }^{10} \mathrm{~B}$ (native). Atom $\%{ }^{10} \mathrm{~B}$ (sample) was measured by ICP-MS. Atom $\%{ }^{10} \mathrm{~B}$ (native) is the atom $\%{ }^{10} \mathrm{~B}$ occurring naturally $(19.8 \%)$. The percent $\mathrm{B}$ derived from the application (\% B dff) was calculated as follows: $\% \mathrm{~B}$ dff $=$ (atom $\%{ }^{10} \mathrm{~B}$ excess/atom $\%{ }^{10} \mathrm{~B}$ application) $\times 100$, where atom $\%{ }^{10} \mathrm{~B}$ application is the atom $\%{ }^{10} \mathrm{~B}$ of the applied $\mathrm{B}(96.75 \%)$.

A randomized complete-block design was used for both experiments. An F test was used to identify significant differences between treatments.

Results are consistent with observations on 'Italian' plum (Hanson et al., 1985) and indicate that absorbed B was transported from the leaves of several deciduous tree fruit species, with the most rapid export occurring soon after treatment (Fig. 1). Boron sprays had increased the B content of leaves by $90 \%$ (cherry) to $185 \%$ (apple) 3 days after treatment (Fig. 1). The B content of treated apple, pear, and plum leaves declined rapidly thereafter and approached levels in control leaves 9 days after treatments. The B content of treated cherry leaves remained higher than control levels for 22 days, suggesting that the rate of export may be slower in this species. Boron concentrations (dry-weight basis) in treated leaves were $88 \mu \mathrm{g} \cdot \mathrm{g}^{-1}$ (plum), $84 \mu \mathrm{g} \cdot \mathrm{g}^{-1}$ (apple), $68 \mu \mathrm{g} \cdot \mathrm{g}^{-1}$ (cherry), and $45 \mu \mathrm{g} \cdot \mathrm{g}^{-1}$ (pear) 3 days after treatment and decreased thereafter at similar rates as $\mathrm{B}$ content (data not presented). Baron concentrations in control leaves did not change significantly over the sampling period and averaged $44,42,41$, and $25 \mu \mathrm{g} \mathrm{B} / \mathrm{g}$ in cherry, plum, apple, and pear, respectively.

The use of stable isotopes also indicated that applied B moved readily from cherry leaves (Fig. 2). Leaves were first sampled 1 day after treatments were applied because leaf B levels changed most rapidly soon after treatments in the previous study. Treated leaves contained $11.5 \mu \mathrm{g}$ more total B than control leaves 1 day after treatment (Fig. 2). The B content of treated leaves declined with time and was only slightly higher than that of control leaves 26 days after treatment. The quantity of B originating from the applied solutions (calculated from the atom \% excess of treated leaves) was $11.2 \mu \mathrm{g} \mathrm{B} / \mathrm{leaf} 1$ day after treatments and $0.9 \mu \mathrm{g} \mathrm{B} / \mathrm{leaf} 26$ days after treatments (Fig. 2).

The effect of treatments on B concentrations in branch parts other than leaves (Table 1) suggests that B exported from leaves is retained primarily in tissues close to treated leaves. Baron concentrations in buds subtending treated leaves and in wood and bark tissue to which treated leaves were attached were increased by $B$ treatments, with the greater increase observed in buds. The B concentrations in branch parts sampled from sections located immediately basal to treated branch apices were either not influenced by treatments (wood, bark) or increased slightly (buds). 
Table 1. Boron concentrations and atom $\%{ }^{10} \mathrm{~B}$ excess in 'Montmorency' sour cherry branch parts sampled 2 Nov., following foliar B applications on 16 Sept.

\begin{tabular}{|c|c|c|c|c|}
\hline $\begin{array}{l}\text { Branch } \\
\text { part }\end{array}$ & Boron & $\begin{array}{c}\text { Total B } \\
\left(\mu g \cdot g^{-1} \text { dry wt }\right)\end{array}$ & $\begin{array}{c}\text { Atom } \\
\text { excess }^{z} \\
(\%) \\
\end{array}$ & $\begin{array}{c}\text { B from } \\
\text { treatment } \\
(\% \text { of total })^{2}\end{array}$ \\
\hline \multicolumn{5}{|c|}{ Apical section ${ }^{y}$} \\
\hline \multirow[t]{2}{*}{ Wood } & - & 8.0 & .... & -.- \\
\hline & + & $8.9^{*}$ & $12.1 \pm 0.64$ & $12.5 \pm 0.7$ \\
\hline \multirow[t]{2}{*}{ Bark } & - & 22.1 & -.. & -.. \\
\hline & + & $25.3^{*}$ & $17.6 \pm 2.8$ & $18.2 \pm 3.4$ \\
\hline \multirow[t]{2}{*}{ Buds } & - & 45.1 & -.. & -.. \\
\hline & + & $57.7^{*}$ & $27.6 \pm 0.81$ & $28.5 \pm 1.1$ \\
\hline \multicolumn{5}{|c|}{ Basal sectiony } \\
\hline \multirow[t]{2}{*}{ Wood } & - & 8.0 & -.- & --- \\
\hline & + & $7.8^{\mathrm{NS}}$ & $1.2 \pm 0.6$ & $\cdots$ \\
\hline \multirow[t]{2}{*}{ Bark } & - & 22.0 & $\quad \ldots$ & $\ldots$ \\
\hline & + & $22.1^{\mathrm{NS}}$ & $0.6 \pm 0.7$ & ... \\
\hline \multirow[t]{2}{*}{ Buds } & - & 43.0 & --- & ... \\
\hline & + & $46.5^{\mathrm{NS}}$ & $8.2 \pm 2.5$ & $8.5 \pm 3.0$ \\
\hline
\end{tabular}

${ }^{2}$ Values are means of six observations $\pm \mathrm{SE}$.

${ }^{Y}$ Apical section comprised of branch parts subtending treated leaves. Basal sections collected immediately adjacent to treated branch sections.

$\mathrm{Ns}$, Nonsignificant or significant differences between treatments, $P=0.05$, respectively, by $\mathrm{F}$ test.

It is unclear why B moved freely out of leaves in these studies but exhibits limited mobility undermost conditions. The relative mobility of B depends on tissue B concentrations. Skok and McIlrath (1958) found that in plants supplied adequate $\mathrm{B}$, a significant percentage of tissue $B$ is dialyzable, whereas dialyzable B declines to near zero in B-deficient plants. They suggested that the dialyzable fraction of tissue B may be freely mobile, whereas the nondialyzable fraction may represent $\mathrm{B}$ that is not freely mobile. The immobile fraction may be bound to polysaccharides in cell walls (Bowen and Nissen, 1976). The present study demonstrates that applied B moves relatively freely out of leaves, while the B content of untreated leaves remains unchanged. This result suggests that applied B enters a mobile pool of tissue B.

Although rain could conceivably leach $\mathrm{B}$ from leaves, it is doubtful that leaching caused the rapid decline in leaf $\mathrm{B}$ content observed in these studies. In 1988, only $10 \mathrm{~mm}$ of rain fell during the two weeks following treatments when leaves lost B most rapidly. In 1989, $14 \mathrm{~mm}$ of rain fell after treatments were applied but before the first leaves were sampled. No rain fell between the first and third sampling dates in 1989. The fact that similar results have been observed in 'Italian' prune trees covered with plastic cages to prevent rain from falling on leaves (Hanson et al., 1985) also indicates that the decline in leaf B levels is a result of export rather than leaching.

Whether the washing procedure used in this study was adequate to remove all B from the leaf surface is not known. However, since the B content of treated leaves usually declined to levels in control leaves, it is unlikely that large quantities of B remained on the leaf surface after washing.

The application of enriched stable isotopes of $\mathrm{B}$ and isotope ratio analysis by ICP-MS appears to be a useful method for studying long-distance transport of Bin plants. Measurements of ${ }^{10} \mathrm{~B}$ : ${ }^{11} \mathrm{~B}$ ratios were reproducible (coefficient of variation $=4 \%$ to $6 \%$ ), and enriched isotope is relatively inexpensive.

Fall B sprays increased fruit set and yield in plum, whereas sprays during bloom did not (Chaplin et al., 1977). Applied B appeared to move from leaves to flower buds in the fall and into flowers the following spring (Hanson et al., 1985). These studies indicate that fall-applied B may move in a similar manner in other deciduous tree fruit species. Additional studies are needed to determine if fall $\mathrm{B}$ applications may increase fruit set of other species.

\section{Literature Cited}

Benson, N. R., E.S. Degman, and I.C. Chmelis. 1961. Translocation and re-use of boron in broccoli. Plant Physiol. 36:296-301.

Bowen, J.E. and P. Nissen. 1976. Boron uptake by excised badeyroots. I. Uptake in the free space. Plant Physiol. 57:353-357.

Charnel, A.R. and A.-M. Andreani. 1985. Demonstration of the penetration of boron in apple fruit using an enriched stable isotope. HortScience 20:907-908.
Charnel, A. R., A.-M. Andreani, and J. Eloy. 1981. Distribution of foliar-applied boron measured by spark-source mass spectrometry and laserprobe mass spectrography. Plant Physiol. 67:457-459.

Chaplin, M. H., R.L. Stebbins, and M.N. Westwood. 1977. Effect of fall-applied boron sprays on fruit set and-yield of 'Italian' prune. HortScience 12:500-501.

Eaton, F.M. 1944. Deficiency, toxicity and accumulation of boron in plants. J. Agr. Res. 69:237-277.

Epstein, E. 1973. Flow in the phloem and the immobility of $\mathrm{Ca}$ and $\mathrm{B}$ : A new hypothesis in support of an old one. Experiential 15:133-134.

Eschrich, W., H.B. Currier, S. Yamaguchi, and R.B. McNairn. 1965. The influence of increased callose formation upon the transport of assimilates in sieve tubes. Planta 65:49-64.

Gregoire, D.C. 1987. Determination of boron isotope ratios in geological materials by inductively coupled plasma mass spectrometry. Anal. Chem. 59:2479-2484.

Gupta, U.C. and D.C. Munro. 1969. The boron content of tissues and roots of rutabagas and of soil as associated with brown-heart conditions. Soil Sci. Soc. Amer. Proc. 33:424-426.

Hanson, E.J., M.H. Chaplin, and P.J. Breen. 1985. Movement of foliar applied boron out of leaves and accumulation in flower buds and flower parts of 'Italian' prune. HortScience 20:747-748.

Kienholz, J.R. 1942. B deficiency in pear trees. Phytopathology 32:1082-1086.

Martini, F. and M. Theillier. 1975. Study, with the help of the ${ }^{10} \mathrm{~B}(\mathrm{n}, \mathrm{a})^{7} \mathrm{Li}$ nuclear reaction, on the redistribution of boron in white clover after foliar application. Nwsl. Appl. Nuclear Methods Biol. Agr. 4:26-29.

McIlrath, W.J. 1965. Mobility of boron in several dicotyledonous species. Bet. Gaz. 126:27-30.

Mengel, K. and E.A. Kirkby. 1987. Boron, p. 559-572. In: Principles of plant nutrition. International Potash Inst., Worblaufen-Bern, Switzerland.

Oertli, J.J. and W.F. Richardson. 1970. The mechanism of boron immobility in plants. Physiol. Plant. 23:108-116.

Rennie, R.J. and D. A. Rennie. 1983. Techniques for quantifying $\mathrm{N}_{2}$ fixation in association with nonlegumes under field and greenhouse conditions. Can. J. Microbial. 29:1022-1035.

Scott, L.E. and A.L. Schrader. 1947. Effect of alternating conditions of boron nutrition upon growth and boron content of grape vines in sand culture. Plant Physiol. 22:526-537.

Skok, J. and W.J. McIlrath. 1958. Distribution of boron in cells of dicotyledonous plants in relation to growth. Plant Physiol. 33:428-431.

Wightman, K. A., F.N. Hewetson, N.F. Childers, and D.W. Buchanan. 1970. Effect of calcium, boron and naphthalene acetamide sprays on cork spot and mineral content of York Imperial apple. J. Amer. Soc. Hort. Sci. 95:23-27.

Zen-Hong Shu, M. Rutzke, and G.H. Oberly. 1989. Boron (B) mobility in one-year-old 'Red Haven' peach trees. ASHS Annu. Mtg., Tulsa, Okla., Prog. \& Abstr. p. 105. 